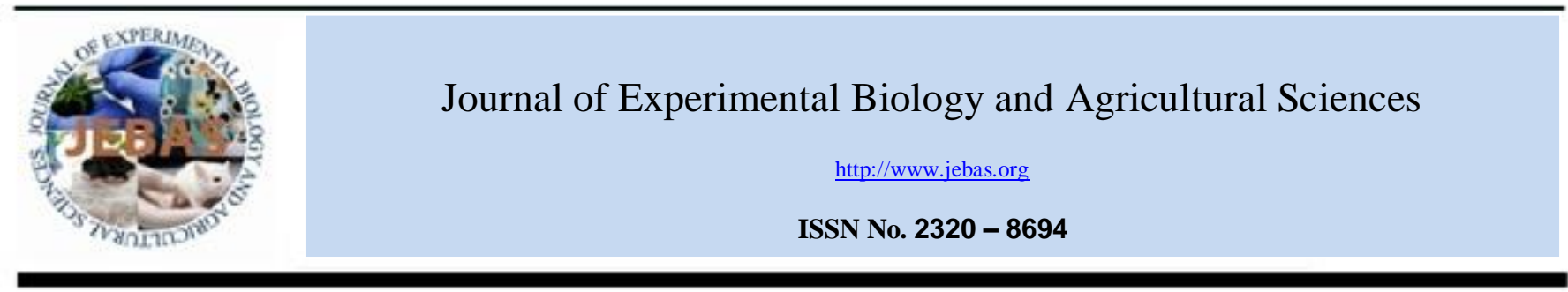

\title{
AGROMORPHOLOGICAL VARIABILITY OF PEARL MILLET (Pennisetum glaucum (L.) R. Br.) CULTIVARS GROWN IN BENIN
}

\author{
Rollande Aladé Dagba ${ }^{*}$, , Antoine A. Missihoun ${ }^{1}$, Hubert Adoukonou-Sagbadja ${ }^{1}$, Merveille K. Savi ${ }^{2}$, \\ Corneille Ahanhanzo ${ }^{1}$, Clément Agbangla ${ }^{1}$ \\ ${ }^{1}$ Laboratory of Genetics and Biotechnology, University of Abomey-Calavi, 01 BP 526, Cotonou, Benin \\ ${ }^{2}$ Laboratory of Biomathematics and Forest Estimations, University of Abomey-Calavi, 05 BP 1752,Cotonou, Benin
}

Received - July 23, 2015; Revision - August 10, 2015; Accepted - September 07, 2015

Available Online - October 20, 2015

DOI: http://dx.doi.org/10.18006/2015.3(5).394.406

KEYWORDS
Pearl millet
Botanical race
Genetic resources
Conservation strategies
Benin

\begin{abstract}
The agromorphological variability between various pearl millet cultivars was evaluated to examine the structure of millet in Benin Republic. Therefore, Forty-two (42) cultivars of pearl millet were collected from four agro-ecological areas viz North Extreme Zone (AEZ1), cotton Zone of northern (AEZ2), Food Zone of South-Borgou (AEZ3) and West-Atacora Zone (AEZ4) of Benin Republic. The experimentation was conducted on Ahossougbéta farm in the town Abomey-Calaviby using alpha lattice design in order to access thirty-three (33) agromorphological characters (seventeen (17) quantitative and sixteen (16) qualitative characters). The canonical discriminant analysis, principal component analysis and hierarchical ascendant classification has identified three morphological classes based on 16 quantitative traits and 8 qualitative discriminating Wilks'Lambda $(\mathrm{P}<0.0001)$. According to vegetative cycle, agroecological zones and botanical race, the distribution of cultivars has regrouped the three classes in two great groups of importance for the improvement of the millet resources. The first one group established withthe early cultivars $(58.33 \%)$ to yellow grain $(83.33 \%)$, long candle $(58.23 \mathrm{~cm}$ Valeur test +5.23 ) with low seed production characteristics $(\mathrm{P} 1000=8.68 \mathrm{~g} \mathrm{Vt}-4.64)$. Itresults from ZAE1 $(83 \%)$ and ZAE2 (17\%) and belong to globosum, typhoides and leonis races.
\end{abstract}

* Corresponding author

E-mail: rollandedagba@gmail.com (Rollande Aladé Dagba)

Peer review under responsibility of Journal of Experimental Biology and Agricultural Sciences.

Production and Hosting by Horizon Publisher (www.myvision.webs.com/horizon.html)

All rights reserved.
All the article published by (Journal of Experimental Biology and Agricultural Sciences) / CC BY-NC 4.0

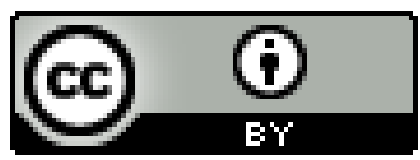




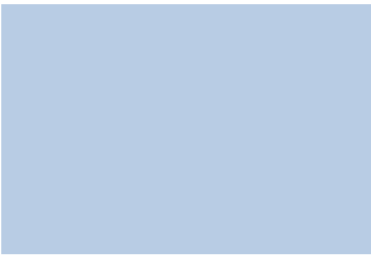

The second group is trained of late cultivars (90\% class 2 and $94.12 \%$ class 3 ) to grey and darkgrey grains $(72.73 \%)$, short candle $(21.12 \mathrm{~cm} \mathrm{Vt}-2.33$ and $22.38 \mathrm{~cm} \mathrm{Vt}-2.77)$ offering the best vegetative development characteristics (Class2 and Class3) and the seed yield (Class 3). Results of the studyrevealed the trade routes between agroecological zones and millet producer ethnic groups of Benin. These results are significantly important for the definition of strategies for improvement and conservation of millet genetic resources in Benin.

\section{Introduction}

Pearl millet (Pennisetum glaucum (L.) R. Br; Gramineae) is a cereal grown in the arid tropical region and semi-arid areas of Asia and Africa. It's a staple food of most of the countries in these two regions. According to Claessens et al. (2012) these two continents producedpearl millet crop in 29 million hectares areas for consumption of over 90 million peoples, it also serves as a forage crop in Europe and the United States (Beningaet al., 2011). Millet is highly cross-pollinated with outcrossing rate of over $85 \%$ (Rai et al., 2007). In Domesticated West Africa (3500 years BP), it was cultivated everywhere in the Sahelian and tropical countries (D'Andrea et al., 2001; D'Andrea \& Casey, 2002). Due to its high ability to adapt in adverseenvironmental conditions and to survive in infertile soils where other grains can't resist this crop has very high importance in arid areas of African countries (Tostain, 1994).It is one of the cereals that provide high food security of Sahelian populations (Benzançon \& Pham, 2004).

By understanding the importance of this crop in the Sahel, various international institutions such as Bioversity International (ex IPGRI) ; IRD (ex ORSTOM) and ICRISAT have developed pearl millet improvement and conservation programs in most of the West Africa countries (Niger, Mali, Togo, Burkina Faso, Senegal, Guinea, Cameroun), these programme help to overcome the problem of food insecurity. Surveys were conducted in all these countries to make the program really perfect and happen. Millet collections were obtained and used as the base material in several studies. Many tests based on morphological traits were conducted to assess the genetic diversity of millet. Benzançon et al. (1994) classified it into two major groups (early and late) millets in West Africa and confirm that they may be structured differently in concerning descriptors and treatment methods used by a given author.

In Burkina Faso, Bono (1973) identified two groups of millet grown from morphological and botanical characteristics (the candle length and shape, number of high-yielding spikelet per involucre, spine diameter and bristle ornamentation). Furthermore, Brunken et al. (1977) identified four African races based on the ratio between the length and width of the seeds. Similarly, Marchais et al. (1993) were identified six geographic groups based on 14 botanical characters from Niger. Zangré et al. (2009) divided into two groups a population of seventy (70) ecotypes of millet collected in eight regions of Burkina Faso on the basis of the vegetative cycle, yield and morphological traits. Similarly, In Cote d'Ivoire, Akanvou et al. (2012) has identified two groups based on 11 morphological characters.

In Benin, Niangado \& Combes (1978) have revealed the existence of 126 cultivated forms and a significant phenotypic variability but until there are no significant studies have been made on millet genetic characterization. Its culture relegated at the second plan in research and development programs. Its production is very limited due to the constraints (irritation of the skin, weeding, excessive rain, soil quality, attacks by birds, termites and livestock havoc the abandoned thinning and lodging) and to the preference shown by the producers for maize and sorghum appears to be more productive and adapting better to the Beninese soil and climatic conditions. However, it subsists through tradition and customs both on cultural, religious and culinary (Clement, 1985; Dagba et al., 2015) but can cause the loss of diversity or lead to a genetic erosion. A new exploration and collection organized in 2013 and 2014 across the North of Benin helped save 42 accessions of cultivated form (Dagba et al., 2015). Under the effect of natural and human selection, local varieties or accessions involving these forms could accumulate genetic diversity that might be poorly exploited in the management of these resources. This study aimed to characterize the diversity in agro morphological plan of millet cultivars collected in Benin. It will specifically determine the level of morphological diversity of millet cultivars and also identify the structure into distinct groups and analyse the potential of cultivars productivity.

\section{Materials \&Methods}

\subsection{Materials}

\subsubsection{Study areas}

The experimentations were conducted at Ahossougbéta farm in the town of Abomey-Calavi located between $7^{\circ} 30^{\prime}-9^{\circ} 45^{\prime} \mathrm{N}$. The soil ofthis zone is mainly sandy and ferralitic (Assogbadjoet al., 2006). The rainfall is bimodal at two humidseasons (April-July and October-November) and two dryseasons (August-September and December-March) with an annual total rainfall varying between $800-1200 \mathrm{~mm}$ in the West and $1000-1400 \mathrm{~mm}$ in the East. The relative humidity varies between $69 \%$ and $97 \%$ and the temperature between $25^{\circ} \mathrm{C}$ and $29^{\circ} \mathrm{C}$ (MEPN, 2008). 
Table 1 List of millet cultivars collected according to ethnic groups, localities, towns Departments AEZ and code.

\begin{tabular}{|c|c|c|c|c|c|c|c|c|}
\hline Agroecological Zones & Covered districts & Localities & No & Name of the cultivars & Name of the accessions & Vegetative Cycle & Codes & Ethnic groups \\
\hline ZAE4 & Natitingou & Taghayè & 1 & Yèyo mata & Yèyo mata & Late (4-6months) & Ytag & Otamari \\
\hline ZAE4 & Natitingou & Tchoumi-Tchoumi & & & Yèyo mata & & Ytt & Otamari \\
\hline ZAE4 & Boukombé & Koutchagou/Koutagou & & & Yèyo mata & & Ykt & Otamari \\
\hline ZAE4 & Boukombé & Kounakokou & & & Yèyo mata & & Ykn & Otamari \\
\hline ZAE4 & Boukombé & Kouponkou/Kouporgou & & & Yèyo mata & & Ykp & Otamari \\
\hline ZAE4 & Boukombé & Tabouota & & & Yèyo mata & & Ytab & Otamari \\
\hline ZAE4 & Toukountouna & Kokobrè/Kokoko & & & Yèyo mata & & Yko & Otamari \\
\hline ZAE3 & Bembèrèkè & Dangbinikou/Dananzi & & & Yèyo mata & & Yda & Otamari \\
\hline ZAE3 & Bembèrèkè & Saoré & & & Yèyo mata & & Ysa & Otamari \\
\hline ZAE3 & Bembèrèkè & Travo/Ouenou & & & Yèyo mata & & Ytr & Otamari \\
\hline ZAE4 & Matéri & Polohoun/Firihoun & 2 & Itoura & Itoura & Late (5 months) & Ipo & Berba \\
\hline ZAE4 & Matéri & Merhoun & & & Itoura & & Ime & Berba \\
\hline ZAE4 & Toukountouna & Wabou & 3 & Sowawia & Sowawia & Late (4-5 months) & Swa & Wama \\
\hline ZAE4 & Toukountouna & Tchakalakou & & & Sowawia & & Stc & Wama \\
\hline ZAE4 & Ouaké & Tchalinga & 4 & Amala & Amala & Late (4 months) & Atc & Lokpa \\
\hline ZAE4 & Djougou & Sosso & & & AmalaKoupètè & & Akps & Lokpa \\
\hline ZAE4 & Djougou & Sosso & & & Amalakouhloumè & & Akhs & Lokpa \\
\hline ZAE4 & Copargo & Karum & 5 & Naali & Na sowli & Early (3 months) & Nka & Tchila \\
\hline ZAE4 & Ouaké & Gnagbakabia & 6 & Mawoairi & Mawoairiranéiri & Late (4 months) & Mgn & Peuhl \\
\hline ZAE4 & Cobly & Tapoga & 7 & Yotorika & Yotorika & Late (4-5 months) & Ytap & Kountèba \\
\hline ZAE3 & Bembèrèkè & Sakarou & 8 & Ayo & Ayoyantè & Late (5 months) & Asa & Niendé \\
\hline ZAE3 & Kouandé & Oroukayo & 9 & Yom mali & Yom mali & Late (4-5 months) & Yor & Natemba \\
\hline ZAE1 & Karimama & Birni-lafia & 10 & Haini & HainiKiré & Early (3 months) & $\mathrm{Hbl}$ & Dendi \\
\hline ZAE1 & Malanville & Toumboutou & & & HainiKiré & & Hto & Dendi \\
\hline
\end{tabular}




\begin{tabular}{|c|c|c|c|c|c|c|c|}
\hline 397 & & & & & & & Dagba et al \\
\hline ZAE1 & Malanville & Madecali & & HainiKiré & & Hma & Dendi \\
\hline ZAE1 & Malanville & Garou-Tédji & & HainiKiré & & Hgt & Dendi \\
\hline ZAE1 & Malanville & Guéné & & Hainikiré & & Hgu & Dendi \\
\hline ZAE1 & Malanville & Garou-Tédji & & HainiKiréDogo & & Hdgt* & Dendi \\
\hline ZAE1 & Karimama & Birni-lafia & 11 Bandadagou & Bandadagou & Early (2-3 months) & Ban & Dendi \\
\hline ZAE1 & Malanville & Toumboutou & 12 Somna & Somna & Late (4-5 months) & Sto & Dendi \\
\hline ZAE1 & Malanville & Madecali & & Somna & & Sma & Dendi \\
\hline ZAE1 & Malanville & Garou-Tédji & & Somna & & Sgt & Dendi \\
\hline ZAE1 & Malanville & Guéné & & Somna & & Sgu & Dendi \\
\hline ZAE2 & Banikoara & Soroko & 13 Gbè & GbèSk & Late (4-6 months) & Gso* & Bariba \\
\hline ZAE2 & Banikoara & Ouagou/Wagou & & Gbè $\mathrm{Ou}$ & & Gou & Bariba \\
\hline ZAE3 & N'Dali & Binansi & & GbèKpika & & Gbp & Bariba \\
\hline ZAE3 & N'Dali & Binansi & & GbèWonka & & Gbg & Bariba \\
\hline ZAE2 & Kandi & Pèdè & 14 Iya & Iyakou & Late (4 months) & Ipe* & Mokolé \\
\hline ZAE2 & Kandi & Gogbèdè & & Iyassè & Early (2 months) & Igo & Mokolé \\
\hline ZAE2 & Kandi & Bensékou & 15 Wéa & Wéagban & Late (4months) & $\mathrm{Wbb}$ & Bo \\
\hline ZAE2 & Kandi & Bensékou & & Wéaguézénon & & $\mathrm{Wgb}$ & Bo \\
\hline ZAE2 & Kandi & Bensékou & $16 \quad \mathrm{Naa}$ & Naaténon & Early (3 months) & Nbe & Bo \\
\hline
\end{tabular}

* Undeveloped Cultivars 
Table 2 List of quantitative and qualitative traits selected (IBPGR \& ICRISAT, 1981, revised in 1993)

\begin{tabular}{|c|c|c|c|c|c|}
\hline $\mathbf{N}^{\circ}$ & Quantitative variables & Codes & $\mathbf{N}^{\circ}$ & Qualitatives variables & Codes \\
\hline 1 & Plant height $(\mathrm{cm})$ & $\mathrm{Hp}$ & 1 & Candleshape & $\mathrm{FCh}$ \\
\hline 2 & Stem diameter $(\mathrm{cm})$ & Dt & 2 & Candledensity & Dech \\
\hline 3 & Number of leaves & $\mathrm{Nf}$ & 3 & Seedcolor & $\mathrm{Cgr}$ \\
\hline 4 & Leaflength $(\mathrm{cm})$ & Lf & 4 & Glumes color & $\mathrm{Cgl}$ \\
\hline 5 & Leaf width $(\mathrm{cm})$ & If & 5 & Leafcolor & $\mathrm{Cf}$ \\
\hline 6 & Internodelength $(\mathrm{cm})$ & Len & 6 & Bristlecolor & Cs \\
\hline 7 & Leaf sheath length $(\mathrm{cm})$ & $\mathrm{Lg}$ & 7 & Seedshape & $\mathrm{Fg}$ \\
\hline 8 & Leafbladelength $(\mathrm{cm})$ & Ld & 8 & Node pigmentation & Pin \\
\hline 9 & Leafbladewidth $(\mathrm{cm})$ & ld & 9 & Internodes pubescence & Puen \\
\hline 10 & Total number of tillers & $\mathrm{Ntt}$ & 10 & Node pubescence & Pun \\
\hline 11 & Number of productive tillers & Ntp & 11 & Bristlelength & Ls \\
\hline 12 & Number of secondary stem & Nts & 12 & Bristledensity & Ds \\
\hline 13 & Candle length $(\mathrm{cm})$ & Lc & 13 & Bristleornamentation & Os \\
\hline 14 & Exsertion candle $(\mathrm{cm})$ & Diec & 14 & Sensitivity to pour & Sverse \\
\hline 15 & CandleDiameter $(\mathrm{cm})$ & Dc & 15 & Juice flavor & Sjt \\
\hline 16 & Pedunclediameter & $\mathrm{Dp}$ & & & \\
\hline 17 & 1000-grain weight $(\mathrm{g})$ & $\mathrm{P} 1000$ & & & \\
\hline
\end{tabular}

\subsubsection{Plant materials}

Plant material consist 42 cultivars of millet which were collected duringDecember 2012 - January 2013 and December 2013 - January 2014 from 32 localities in northern Benin with 13 different socio-cultural groups. As described by PANABENIN, these localities are situated in four different agroecological zones of Benin viz North Extreme Zone (AEZ1), cotton Zone of northern (AEZ2), Food Zone of South-Borgou (AEZ3) and West-Atacora Zone (AEZ4) (MEPN, 2008) (Table 1). The collection of plant material and its characteristics was made through group discussions based on a semi-structured interview guide.

\subsection{Methods}

\subsubsection{Field experiments}

The racial classification of millet candle collected from different was carried out according to Brunkenet al.(1977) criteriaatLaboratory of Genetics and Biotechnology of Faculty of Sciences and Technology of University of Abomey-Calavi (Benin).

The plant material was assessed using an alpha-lattice experimental design described by Patterson \& Williams (1976) with three repetitions, 7 blocks with 7 landrace varieties per repetition.Each block has seven basic plotsand eachplot contains one cultivar a randomly positioned. The last block of each repetition contains 7 repeated cultivars to offset blocks. The dimension of a basic plot is $0.2 \mathrm{~m}$ on $0.6 \mathrm{~m}$, with a distance dimension of $0.2 \mathrm{~m}$ and $0.4 \mathrm{~m}$ for spacing. Each plot unit has 8 plants. Sowing was done by direct seeding (per hole). The standard cultural and agronomic practices that included thinning and manual weeding at 15 days after sowing were followed. No chemical and organic contribution is brought on the soil.

\subsubsection{Data collection}

The observations on 17 quantitative and 16 qualitative traits selected in the millet descriptor were taken on four random plants in each plot (Table 2).

\subsubsection{Statistical Analysis}

Canonical discriminant analysis (CDA) was performed on the matrix of agromorphological data in other to select the most discriminated variables. An analysis of variance mixed model at two factors (random block and cultivar fixed) was evaluated to compare the selected parameters on cultivars. A multivariate analysis of variance was performed to confirm or refute the trends obtained by analysis of variance. These analyses are made with the $\mathrm{R}$ software by using packages "candisc" (Friendly \& Fox, 2013), "lsmeans" (Russell et al., 2013) and "nlme" (Pinheiro et al., 2013).

The discriminating variables and qualitative data for each cultivar were joined and used to make a grouping into cultivars classes by ascending hierarchical classification method (CHA). Classes were reserved and described by a principal component analysis (PCA) using the quantitative variables. An association of qualitative variables was realized across each class using the Chi2 test. These statistical analyses were performed in the R v2.15 software, by using of package "Facto Mine R" (Husson et al., 2013). 
Table 3 Summary variable selection discriminate

\begin{tabular}{|lccccccc|}
\hline Stage & Variables & $\mathbf{R}^{2}$ partial & F Value & Pr $>\mathbf{F}$ & Lambda-Wilk & Pr $<$ Lambda-Wilk & Averagesquared \\
\hline $\mathbf{1}$ & P1000 & 1 & 33640.70 & $<0.0001$ & 0.00023462 & $<0.0001$ & 0.026 \\
\hline $\mathbf{2}$ & Nts & 0.83 & 37.20 & $<0.0001$ & 0.00004097 & $<0.0001$ & 0.048 \\
\hline $\mathbf{3}$ & Lc & 0.8 & 31.15 & $<0.0001$ & 0.00000824 & $<0.0001$ & 0.069 \\
\hline $\mathbf{4}$ & Nf & 0.63 & 13.49 & $<0.0001$ & 0.00000302 & $<0.0001$ & 0.084 \\
\hline $\mathbf{5}$ & Dc & 0.47 & 6.83 & $<0.0001$ & 0.00000161 & $<0,0001$ & 0.095 \\
\hline $\mathbf{6}$ & Hp & 0.44 & 6.07 & $<0.0001$ & 0.0000009 & $<0.0001$ & 0.102 \\
\hline $\mathbf{7}$ & Lg & 0.38 & 4.67 & $<0.0001$ & 0.00000056 & $<0.0001$ & 0.109 \\
\hline $\mathbf{8}$ & ld & 0.36 & 4.38 & $<0.0001$ & 0.00000036 & $<0.0001$ & 0.118 \\
\hline $\mathbf{9}$ & Ld & 0.33 & 3.77 & $<0.0001$ & 0.00000024 & $<0.0001$ & 0.126 \\
\hline $\mathbf{1 0}$ & Len & 0.31 & 3.50 & $<0.0001$ & 0.00000017 & $<0.0001$ & $<.134$ \\
\hline $\mathbf{1 1}$ & Dp & 0.25 & 2.51 & $<0.0001$ & 0.00000012 & $<0.0001$ & $<0.139$ \\
\hline $\mathbf{1 2}$ & Ntt & 0.23 & 2.32 & $<0.0001$ & 0.0000001 & $<001$ & 0.0001 \\
\hline $\mathbf{1 3}$ & Diec & 0.19 & 1.80 & 0.039 & 0.00000008 & $<0.0001$ & 0.145 \\
\hline $\mathbf{1 4}$ & Lf & 0.21 & 1.98 & 0.0009 & 0.00000006 & $<0.0001$ & 0.153 \\
\hline $\mathbf{1 5}$ & Ntp & 0.18 & 1.6 & 0.0182 & 0.00000005 & $<0.0001$ & 0.156 \\
\hline $\mathbf{1 6}$ & Dt & 0.16 & 1.45 & 0.0491 & 0.00000004 & 0.160 \\
\hline
\end{tabular}

\section{Results}

3.1 Discriminant characters of millet cultivars

The canonical discriminant analysis (CDA) made step by step showed us that among the 17 selected quantitative variables, 16 are discriminating with relatively high $F$ and $R^{2}$ values (Table 3). Only the variable leaf width (lf) has little interest in separating cultivars. These results were confirmed by the statistical work of Wilks'Lambda ( $\mathrm{P}<0.0001)$.

As per the results of this study two canonical axes were selected and showed the high discrimination $99.8 \%$.The first axis explains $99.6 \%$ of the total variance and the second axis totals $0.2 \%$. Adjusted correlation coefficient 0.9997 is highly significant $(\mathrm{P}<0,001)$. The projection of variables on the two canonical axes shows that the variables that discriminate cultivars on the first axis are mainly the length of the candle (Lc), the length of the inter-node (Len), the length of the leaf sheath $(\mathrm{Lg})$, the length of the leaf blade (Ld), stem diameter $(\mathrm{Dt})$, the peduncle diameter (Dp), the number of productive tillers (Ntp), and the leaf blade width (ld), which oppose to variable as number of leaves (Nf), the plant height (Hp), the number of second rods (Nts), the diameter of the candle (Dc), the number of Total tillers (Ntt) (Figure 1). The variable that contributes the most to the definition of the second axis is the weight of 1000 seeds (P1000). The multivariate analysis of variance in terms of the statistical test Wilks $(K=15.19$; $\mathrm{P}<0.001)$ confirms the existence of a difference between the different cultivars.

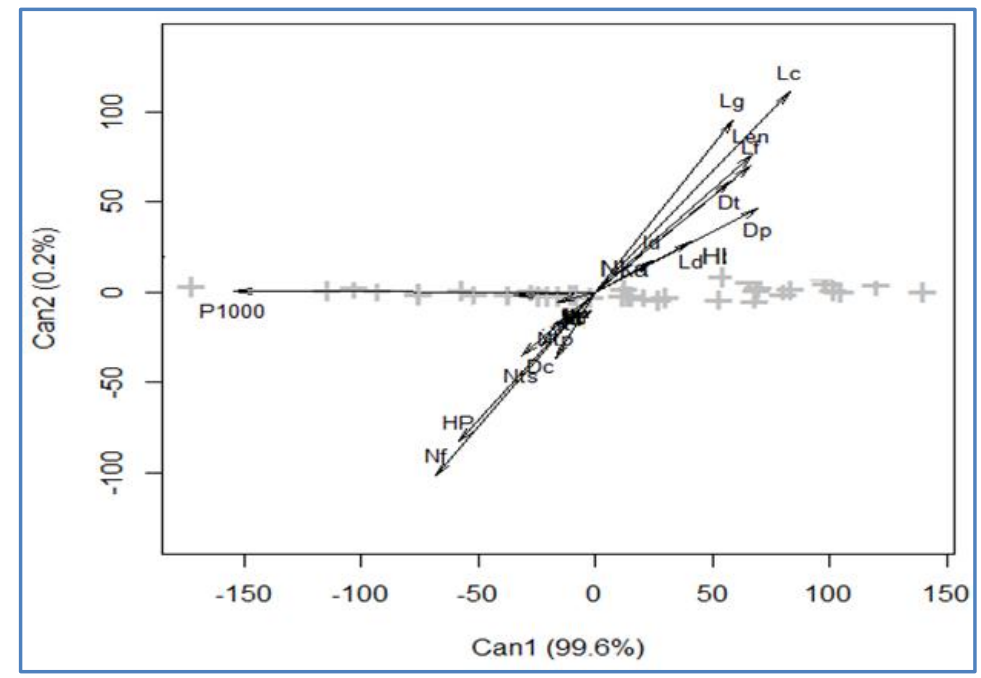

Figure 1 Projection of discriminant quantitative variables in the canonical axis system. 


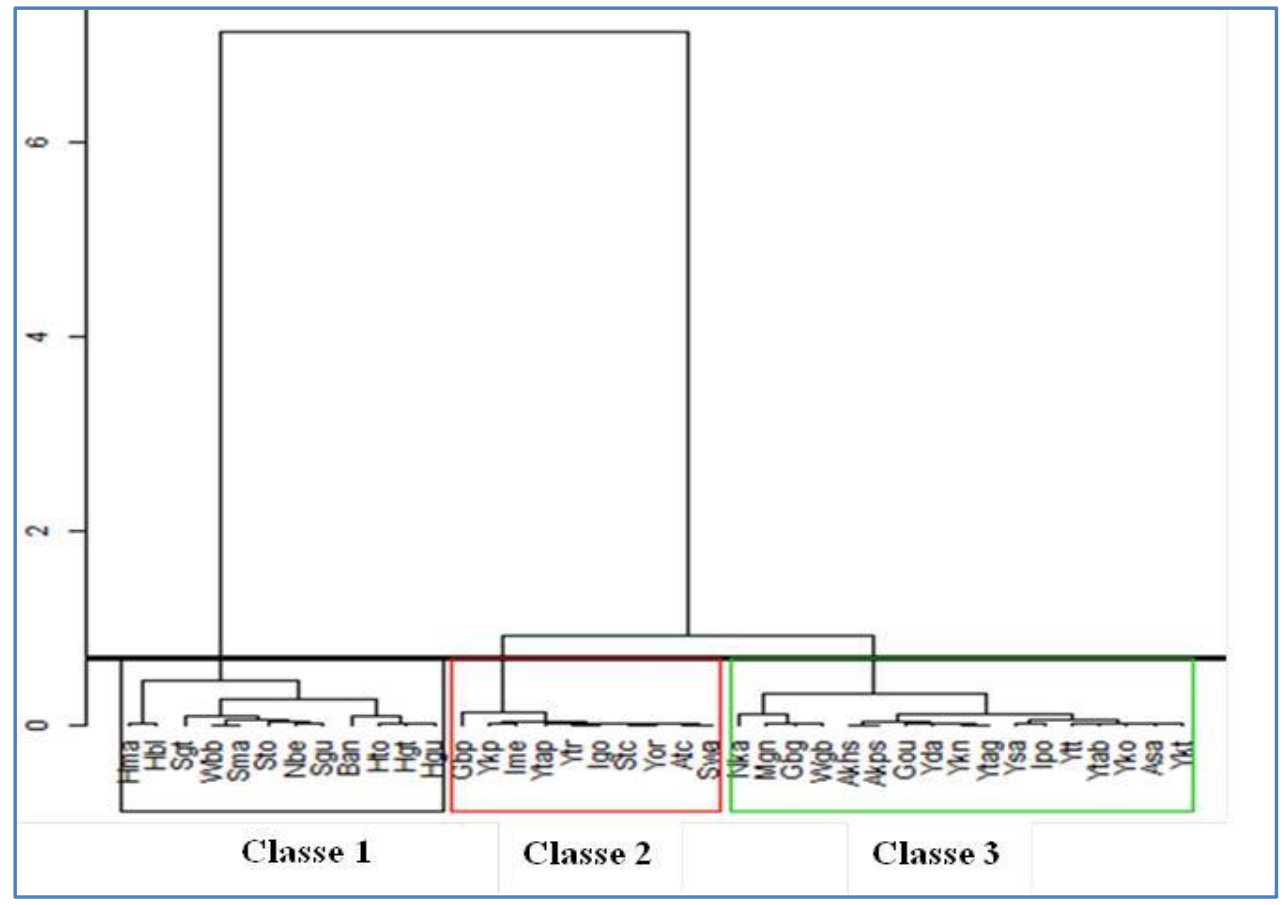

Figure 2 Dendrogram resulting from the hierarchical Ascendant classification of millet cultivars from Benin.

[Legend: Hma : hainikiréMadécali ; Hbl : hainikiréBirni-lafia ; Sgt : somnaGarou-tédji ; Wbb : WéagbanBensékou ; Sma : SomnaMadécali ; Sto : SomnaToumboutou ; Nbe : NanténonBensékou ; Sgu : SomnaGuéné ; Ban : BandadabouBirni-lafia ; Hto : hainikiréToumboutou ; Hgt : hainikiréGarou-tédji ; Hgu : hainikiréGuéné ; Gbp: gbèBinansikpika, Ykp : yeyoKouponkou, Ime : itouraMerihoun ; Ytap : yeyoTapoga ; Ytr : yeyotravo ; Igo: IyassèGogbèdè ; Stc : SowawiaTchakalakou ; Yor : yotorikaOroukayo ; Atc : amalaTchalinga ; Swa : sowawiaWabou ; Nka : nasowliKarum ; Mgn : mawoairiGnangbakabia ; Gbg : gbèBinansiwonka ; Wgb : WéaguézenanBensékou ; Akhs : AmalakouhloumèSosso ; Akps : amalakoupètèSosso ; Gou : gbèOuagou ; Yda : yeyoDangbinikou ; Ykn : yeyoKounakokou ; Ytag : yeyoTaghayè ; Ysa : yeyoSaoré ; Ipo: itouraPolohoun ; Ytt : yeyoTchoumi-tchoumi ; Ytab : yeyoTabota ; Yko : yeyoKokobrè ; ayoyantéSakarou ; Ykt : yeyoKoutchagou]

Table 4 Main characteristics of the various classes formed by the HCA

\begin{tabular}{|c|c|c|c|c|c|c|}
\hline \multirow[t]{2}{*}{ Variables } & \multicolumn{2}{|c|}{ Class 1} & \multicolumn{2}{|c|}{ Class 2} & \multicolumn{2}{|c|}{ Class 3} \\
\hline & Mean & Value test & Mean & Value test & Mean & Value test \\
\hline Dp & 1.166 & 5.504 & 0.561 & -2.881 & 0.634 & -2.529 \\
\hline Lc & 58.232 & 5.227 & 21.120 & -2.330 & 22.381 & -2.773 \\
\hline Lg & 19.801 & 5.155 & 14.016 & -2.512 & 14.492 & -2.538 \\
\hline Lf & 90.540 & 5.095 & 70.489 & -2.465 & 72.057 & -2.526 \\
\hline Dt & 1.338 & 5.029 & 0.847 & -3.146 & - & - \\
\hline Len & 21.048 & 4.736 & - & - & 14.971 & -2.663 \\
\hline Ld & 58.396 & 3.575 & 44.445 & -2.316 & & \\
\hline Id & 4.166 & 2.604 & 3.182 & -3.623 & & \\
\hline Diec & 1.076 & -2.561 & - & - & 3.718 & 2.702 \\
\hline Dc & 2.137 & -2.967 & - & - & 2.634 & 2.660 \\
\hline Ntp & 1.309 & -3.214 & - & - & 2.964 & 4.436 \\
\hline Hp & 3.366 & -4.124 & - & - & 4.625 & 2.556 \\
\hline P1000 & 8.686 & -4.640 & - & - & 19.442 & 2.862 \\
\hline Nf & 14.899 & -4.795 & - & - & 30.031 & 3.268 \\
\hline Ntt & - & - & 4.625 & -2.125 & 6.161 & 3.682 \\
\hline Nts & - & - & - & - & 2.949 & 2.533 \\
\hline
\end{tabular}


Table 5 Test of Independence classes obtained with the variables

\begin{tabular}{|l|c|c|}
\hline Variables & df & P.value \\
\hline Cgr & 8 & $0.0001 *$ \\
\hline Ds & 4 & 0.0004 \\
\hline Os & 4 & 0.0015 \\
\hline Pun & 2 & 0.0017 \\
\hline Sverse & 4 & 0.0024 \\
\hline Fg & 6 & 0.0229 \\
\hline Cs & 6 & 0.0316 \\
\hline FCh & 6 & 0.0338 \\
\hline
\end{tabular}

Legend: Cgr : Seed color, Ds : bristle density ; Os : bristle ornamentation ; Pun : node pubescence ; Sverse : pour sensibility ; Fg : Seed shape ; Cs : bristle color ; Fch : candle shape.

\subsection{Morphological characteristics of millet cultivars}

The morphological diversity analyzed by the method of Hierarchical Ascendant classification has allowed structuringthe variability of millet cultivars from Benin. The dendrogram produced from the 16 discriminant quantitative variables has helped to identify 3 classes that concentrate more than $50 \%$ of the total inertia (Figure 2). The main characteristics of classes are presented in the table 4.

The principal component analysis (PCA) showed that the first two axes explain $57.88 \%$ of the information of the starting matrix, which is sufficient to describe the cultivar characteristics of each class. The projection of quantitative variables in the axis system defined by the principal component (Figure 3 ) revealed that the first axis oppose the stem diameter (Dt), the leaf length (Lf), the internode length (Len), the candle length (Lc), the peduncle diameter (Dp), the leaf blade length $(\mathrm{Ld})$ and leaf sheath length $(\mathrm{Lg})$ at the plant height $(\mathrm{Hp})$, the number of leaves $(\mathrm{Nf})$ and the 1000-grain weight (P1000).The second axis reveals the positive linkage

Cultivars of the second class cover 10 cultivars (25.64\%) which have the lowest values of the total number of tillers (Ntt), the leaf blade length (Ld), the candle length (Lc)(Figure $5 b)$, the leaf length (Lf), the leaf sheath length $(\mathrm{Lg})$, the peduncle diameter $(\mathrm{Dp})$, the stem diameter $(\mathrm{Dt})$, and the leaf blade width (ld). In this class $72.73 \%$ cultivars have a seed color (Cgr) Grey, $90.91 \%$ have a seed shape (Fg), globular and all cultivars has a hairy at the node (Pun).

As for Class 3, it consists of fifteen (17) cultivars (43.58\%) with strong values for the number of productive tillers (Ntp), the total number of tillers ( $\mathrm{Ntt})$, the number of leaves $(\mathrm{Nf})$, 1000- grain weight (P1000), the distance of the excertion (Diec), the diameter of the candle (Dc), the height of the plant (Hp) and number of secondary stems (Nts). $68.75 \%$ of these cultivars have a pour sensibility (Sverse) intermediate and a bristle density (Ds)of compact bristles. between the total number of tillers (Ntt), the number of productive tillers (Ntp), the candle diameter (Dc), the candle exsertion (Diec) and the blade width whichmove in the same direction. The independence test ofChi2 made on the qualitative variables allowed to note that the clusters obtained depends on 8 of the 16 variables in terms of probabilities which are all less than 0.05 (Table 5).

The projection of the classes in the axis system (Figure 4) showed that the first class consists of 12 cultivars i.e. $30.77 \%$ of total studied cultivars and is characterized by the highest values of stem diameter (Dp), the length of the candle (Lc)(Figure 5a), the length of the sheath $(\mathrm{Lg})$, the Leaf length (Lf), diameter of the stem (Dt), the length of the internodes (Len), the flag length (Ld), and the flag width (ld). Among these cultivars, $83.33 \%$ have seed color (Cgr), a pour sensibility (Sverse) low. Similarly, all cultivars bristle ornamentation (Os) hairy. Also half of the class cultivars have a bristle color (Cs) green, a seed shape (Fg) obovate and bristles density (Ds) intermediate.

The distribution of cultivar from AEZ and their vegetative cycle through the three classes obtained show that all classes haveearly and late cultivars but only the first class contains $58.33 \%$ early cultivars while second and third classeshave $90 \%$ and $94.12 \%$ late cultivarsrespectively. In the same way $83 \%$ cultivars of the first camefrom the AEZ1 while rest $17 \%$ came from the AEZ2. These cultivarsare the "hainikiré, somna, bandadabou"(of Dendi) and Naatenon, wéagban" (of Bo). The cultivars of second and third classesgather in AEZ2, AEZ3 and AEZ4. 60\% of cultivars (gbèkpika (Bariba), iyassè (Mokolé), sowawia (Wama), yomali (Natemba), yotorika (Koutemba) anditoura (Berba)) belonging to class 2 and $64.71 \%$ of those Na-sowli (Tchila), mawoairiraneiri (Peulh), gbèwonka (Bariba), amala (Lokpa) and yeyo (Otamari) belonging to class3provide toAEZ4.According to Brunken et al.(1977) the distribution of racial diversity within the classes showed a predominance of globosumrace in the three morphological classes, the existence of thyphoidesrace in all classes and léonisand nigritariumrace specifically in the first and third classes respectively (Figure 6). 


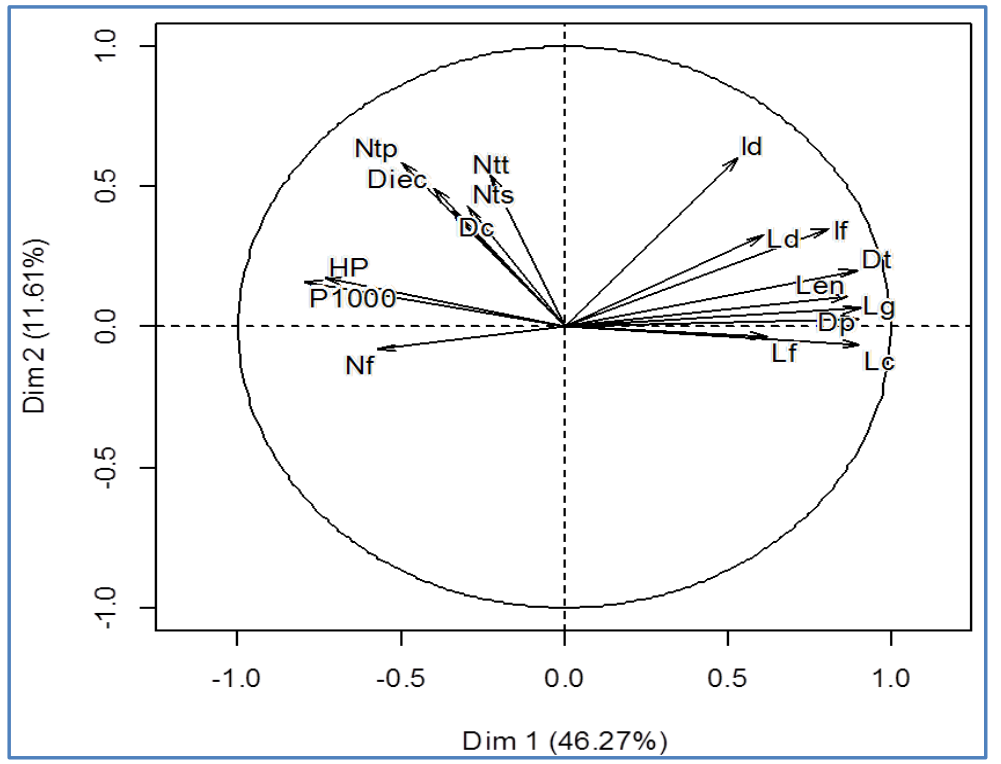

Figure 3 Projection of quantitative variables in the 1 and 2 axis systems.

[Legend: Dt: stem diameter, Lf: leaf length, Len : internode length, Lc : candle length, Dp : peduncle diameter, Ld: leaf blade length, Lg: leaf sheath length, Hp : plant height, Nf : number of leaves, P1000: 1000-grain weight, Ntt: total number of tillers, Ntp: number of productive tillers, Dc: candle diameter, Diec : candle exsertion, ld: leaf blade width.]

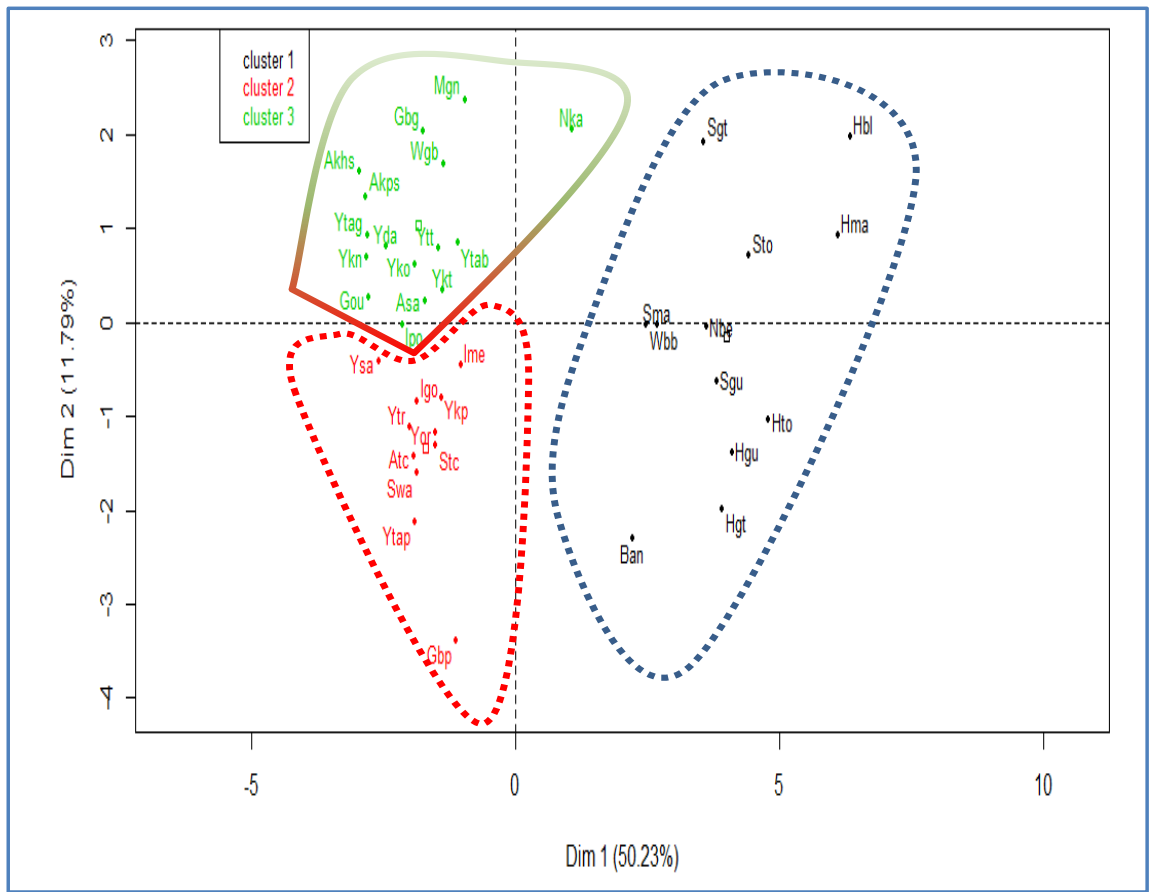

Figure 4 Projection of classes in the axes system. L'ACP result 


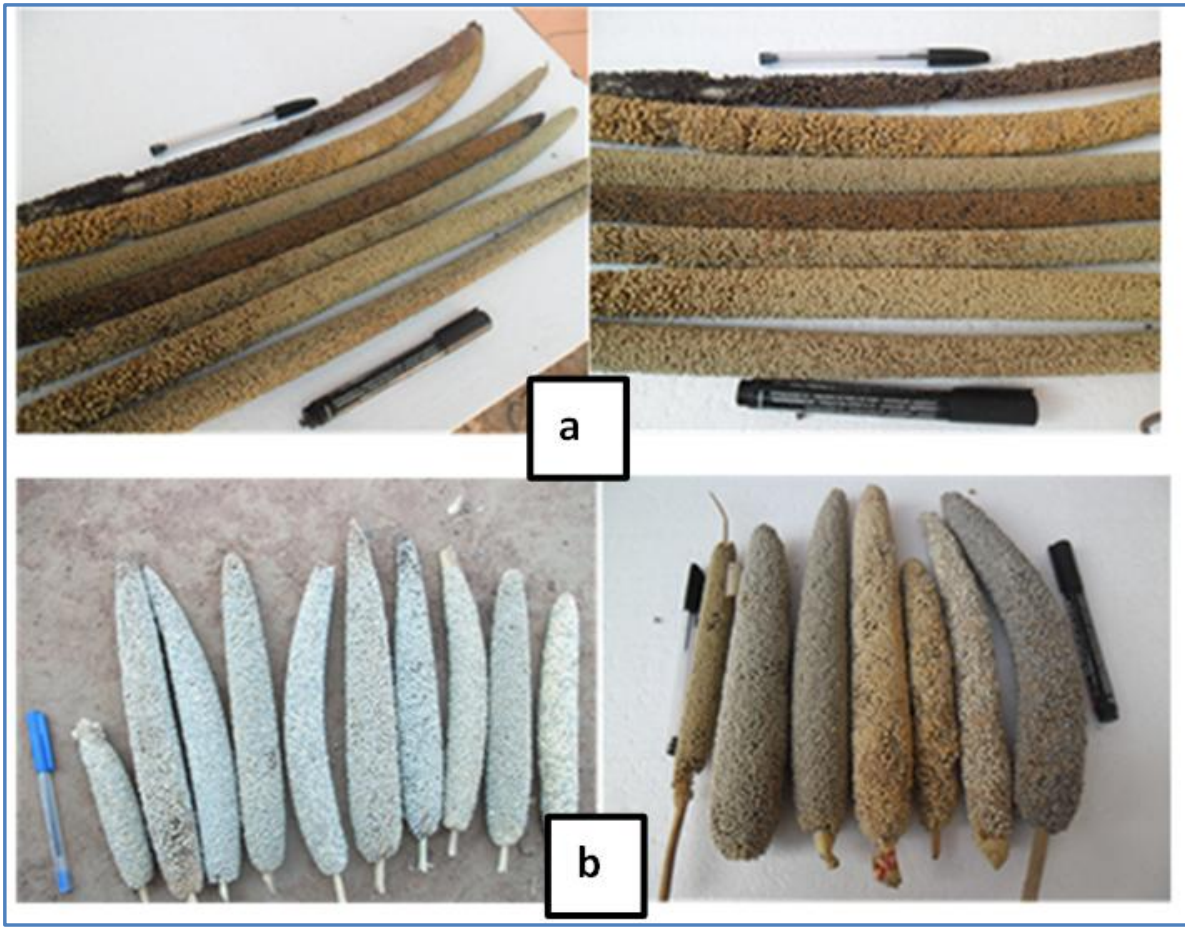

Figure 5 Diversity of millet cultivars collected at Benin as revealed by candle morphology. a: type of the first class candle, $b:$ type of the second and third class candles

\section{Discussion}

The high representativeness of the first two canonical axes demonstrates the existence of a strong phenotypical organization of millet cultivars inBenin. This strong phenotypical organization could be result from the expression of a strong genotypical heterogeneity which will remain to be confirmed by the molecular analyses but also by the influence of the environmental factors. Likewise all selected quantitative variables showed a highly significant difference thus offering better phonotypical differentiation of cultivars confirming the work of Beninga et al., (2011).

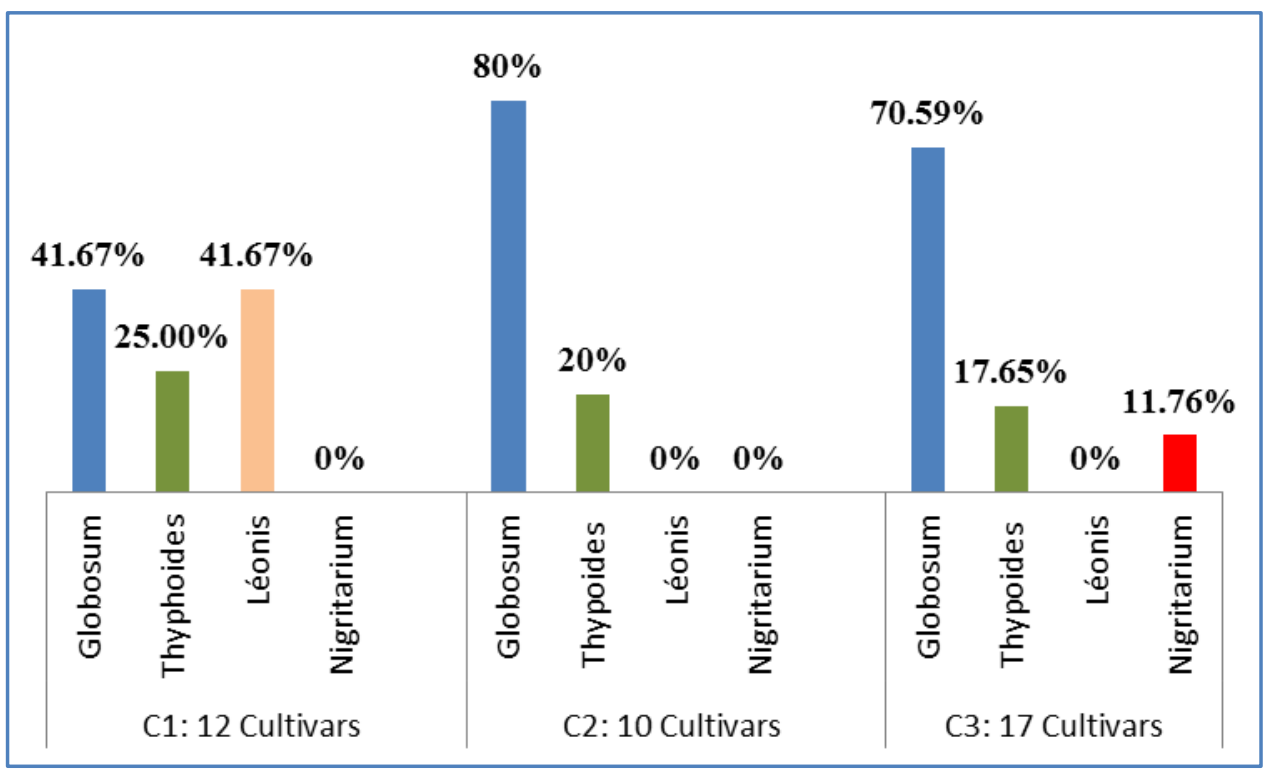

Figure 6 Distribution of racial diversity within morphological classes 
Many analyses through ACD, ACP and CHA associated with qualitative variables showed that the morphological variability of Benin millet cultivars is divided into three classes. These morphological structures uses the strong correlation between some characters like the candle length, the plant height, the number of leaves, the number of productive tillers, the number of secondary stems, the seed colour and the 1000-grain weight and also base itself on the vegetative cycle and agroecological zones.

Thus, the first class formed the group of early cultivars with yellow grain and weak seed yield in spite of the big size of the candles $(58.24 \mathrm{~cm})$. The second and third classes formed the group of the late cultivars, with grey and grey dark grain respectively and short candle $(21.52-22.40 \mathrm{~cm})$, offering the best characteristics of vegetative development. The cultivars of the third class present best characteristics of seed yield with an average of 6.10 total tillers, 2.96 productive tillers and 2.86 secondary productive stems. These results are in agreement with those obtained by Chaudhry et al. (2003). In contrast, Békoye et al. (2011) showed that more the vegetative cycle is long more low are the characteristics of vegetative development and seed yield.

This organization of three morphological classes in early and late groups is similar to that observed by Clement(1985) in Benin; Zongo et al. (1991) in Burkina Faso; Akanvou et al. (2012) in Côte d'Ivoire on the millet. Difference in the Benin cultivars is that the late cultivars group included the cultivar class which presents at the same time a high fodder potential but also seed yield. This difference of class can justify itself by the predominance of cultivars yeyomata at food and religious importance in the cultural area Otamari of AEZ4 (Dagba et al., 2015). The agronomic and ecological systems are susceptible to exercise very variable selective and anthropological pressures on genotypes (Sadiki \& Jarvis, 2005; Robert et al., 2005).

The morphological dissimilarity observed between the phenotypical first class and the set second and third classes can be explained by the maintenance of cultivars under very different evolutionary processes according to agroécological zones studied. That observed between the second and third classes could be the result of an adaptive process which will be able to justify itself by the molecular analyses.

Besides, the structuring of the millet morphological variability based on agro-ecological zones was partially observed. It was reported by several authors on millet in Benin (Clement, 1985); in Côte d'Ivoire (Béninga, 1992; Akanvou et al., 2012), in Burkina Faso (Zangré et al., 2009); in the sub-region revealing similarities between millet of Senegal and Niger; Mali and Burkina Faso (Bono, 1973; Marchais, 1982); of Niger, Nigeria and Senegal (Ouendeba et al., 1995); contrary on Sudanese millet (Bashir et al., 2013) on other speculations as the Sorghum in Benin (Missihoun et al., 2012); the fonio in Togo (Adoukonou-Sagbadja et al., 2007) contrary on the fonio in Niger (Saidou et al., 2014).
This cultivars structuring according to the agroecological zones observed in this study might be due a high frequency of seed exchange of local cultivars among the producers across the zone but also shows the great ways of these exchanges and the bond between the ethnic groups producing of the millet in Benin. Such observations were described by certain authors on others species cultivated in West Africa (Bakasso, 2010; Missihoun et al., 2012, Saïdou et al., 2014). In the same way the racial diversity of the millet local cultivars collected through the classes comes to confirm not only the ways of exchanges between ZAE but also between the close countries like Nigeria, Burkina Faso, Niger and Togo. The predominance of globosum race was already reported by Bono (1973) which explained that it is most common of races to Benin, Ghana, Niger, Nigeria and Togo. It can be explained by the geographical situation of the agroecological zones close to certain countries, in relation to the history of the domestication of the millet. Findings of the present study alsoconfirms by thework of Rai et al. (1997) and Syngenta, (2006) which found that it is the dominant race of the Western zones of the Sahel.

In conclusion, this study exploited the millet cultivars collected in four agroecological zones (North Extreme Zone (ZAE1), cotton Zone of North (ZAE2), food Zone of the South Borgou (ZAE3) and Zone of West-Atacora (ZAE4)) of Benin. It has allowed highlighting the great morphological variability and the rich racial diversity existent between the cultivars of millet of country. It showed also a structuring in three morphological classes being summarized in two great groups on the basis some morphological characters, the vegetative cycle and agroecological zone. These two group present very advantageous for improvement programs. Thus the first group is consisted of first class cultivars, early maturing with yellow grain, long candle, poor seed yield coming from the AEZ1 and AEZ2; the second group formed of second and third classes cultivars, late maturing with grey grain and grey-dark, short candle, high-output to forage ( 2 and 3 Class) and seed (class 3 ) coming from the 2, 3 and 4 ZAE. These results made it possible to define the large geographical areas of morphological diversity necessary for a better collection and a better in situ conservation of the genetic resources of the millet. The data analysed in this study being based on the agromorphological traits, the molecular markers with high density could be used for better concluding the genetic differentiation from local pearl millets cultivated in Benin.

\section{Conflict of interest}

Authors would hereby like to declare that there is no conflict of interests that could possibly arise.

\section{Acknowledgements}

This study was supported by the Government of Benin through the Laboratory of Genetics and Biotechnologies and the scientific council of the University of Abomey-Calavi. We sincerely thank the Professors Romain GLELE KAKAI and Achille E. ASSOGBADJO for critical and technical review of 
the manuscript. We very thank Dr. Arnaud AGBIDINOUKOUN and Dr Romaric VIHOTOGBE for their priceless contribution in the realization of this study. We don't Forget Paulin SEDAH, Relique AGBO, Jack AISSI, Euloge AKOHOU, Géofroy KINHOEGBE and Nadège GNONHOUIN for useful help during perusal.

\section{References}

Adoukonou-Sagbadja H, Wagner C, Dansi A, Ahlemeyer J, Daïnou O, Akpagana K, Ordon F, Friedt W (2007) Genetic diversity and population differentiation of traditional fonio millet (Digitaria spp.) landraces from different agro-ecological zones of West Africa. Theoretical and AppliedGenetics115:917-931.doi: 10.1007/s00122-007-0618$\mathrm{x}$.

Akanvou L, Akanvou R, Kouakou CK, N'DA HA, Koffi KGC (2012) Evaluation de la Diversité agro-morphologique des accessions de mil (Pennisetum glaucum) (L) R.Br) collectées en Côte d'Ivoire. Journal of Applied Biosciences 50: 34683477 .

Assogbadjo AE, Kyndt T, Sinsin B, Gheysen G, Van Damme P (2006) Patterns of Genetic and Morphometric Diversity in Baobab (Adansonia digitata) Populations Across Different Climatic Zones of Benin (West Africa). Annals of Botany 97: 819-830. doi: 10.1093/aob/mcl043.

Bashir E, Ali AM, Ali AM, Melchinger AE, Parzies HK, Haussmann BI(2014) Characterization of Sudanese pearl millet germplasm for agro-morphological traits and grain nutritional values. Plant Genetic Resources 12: 35-47.

Bakasso Y(2010) Ressources génétiques des roselles (Hibiscus sabdariffa L.) du Niger : évaluations agromorphologique et génétique. $\mathrm{PhD}$ thesis submitted to University of Niamey, Niamey.

BékoyeBM, Abdourahamane S, Pierre NAS, Arsène ZBI, MangoaCY (2011) Estimation des paramètres génétiques de quelquesdescripteurs agromorphologiques chez le mil [Pennisetum glaucum (L.) R. Br.]. Journal of Applied Biosciences 43: 2891 - 2898.

Béninga M (1992) Evaluation et utilisation des ressources génétiques des mils et sorgho. Collecte et valorisation des formes sauvages. In Complexes d'espèces, flux de gènes et ressources génétiques des plantes. Colloque international du 810 F-75231 Paris cedex 05 : 73-86.

Bezançon G, Renno JF, Kumar KA(1994)Le mil. CIRAD \& OSRTOM : L'amélioration des plantes tropicales. Montpellier France.

Bezançon G, Pham JL (2004) Ressources génétiques des mils en Afrique de l'Ouest. Editions de l'IRD, Diversité, conservation et valorisation.
Brunken J, de Wet JMJ, Harlan JR (1977)The morphology and domestication of pearl millet. Economic Botany 31:163-174. doi: 10.1007/BF02866587.

Bono M (1973) Contribution à la morpho-systématique des Pennisetum annuels cultivés pour leur grain en Afrique Occidentale francophone. 'L'Agronomie Tropicale. Série 3, Agronomie Générale. Etudes Scientifiques 28 : 229-356.

Chaudhry MH, Subhani GM, Shaheen MS, Saleem U (2003) Correlation and path coefficient analysis in pearl millet (Pennisetum americanum (L.). Pak.).Pakistan Journal of Biological Sciences 6: 597-600.doi: 10.3923/pjbs.2003.597.600.

Claessens L, Gowda CLL, Craufurd P (2012)The importance of millet for food and nutrition security. In: CCAFS, CGIAR, Thornton P, Cramer L (Eds.) Impacts of climate change on the agricultural and aquatic systems and natural resources within the CGIAR's mandate. Research Program on Climate Change, Agriculture and Food Security, Copenhagen.

Clement JC (1985) Les mils pénicillaires de l'Afrique de l'Ouest : Prospections et collectes IBPGRORSTOM. IBPGR, Rome 85/15 -ORSTOM.

Dagba AR, Missihoun AA, Adoukonou-Sagbadja H, Houéhanou TD, Assogbadjo AE, Ahanhanzo C, Agbangla C(2015)Traditionnal knowledge on millet (Pennisetuum glaucum (L.) R. Br) genetic resources conservation in Benin: Local taxonomy and cultivar characteristics. Annales des Sciences Agronomiques (In press).

d'Andrea AC, Casey J (2002) Pearl Millet and Kintampo Subsistence. African Archaeology Review 19: 147-173. doi: 10.1023/A:1016518919072.

d'Andrea AC, Klee M, Casey J(2001) Archaeological evidence for pearl millet (Pennisetum glaucum) in Sub-saharan West Africa. Antique 75: 341-348. doi: http://dx.doi.org/10.1017/S0003598X00060993.

Friendly M, Fox J (2013) Candisc: Visualizing Generalized Canonical Discriminant and Canonical Correlation Analysis. R. package version 0.6-5. http://CRAN.Rproject.org/package $=$ candisc

Husson F, Josse J, Le S, Mazet J (2013) Facto MineR: Multivariate Exploratory Data Analysis and Data Mining with R. $\mathrm{R}$ package version 1.25. http://CRAN.Rproject.org/package $=$ FactoMineR

IBPGR-ICRISAT (1981) Pearl millet descriptors. IBPGR, Rome, Italy.

Marchais L (1982) La diversité phénotypique des mils pénicillaires cultivés au Sénégal et au Mali. Agronomia Tropicale $37: 68-80$. 
Marchais L, Tostain S, Amoukou I (1993) Signification taxonomique et évolutive de la structure génétique des mils pénicillaires. In : Le mil en Afrique, Hamon S(Ed). ORSTOM, Paris, France.

MEPN (2008) Convention cadre des Nation Unies sur le changement climatique. Programme d'action National d'adaptation aux changements climatiques du Bénin (PANABENIN).

Missihoun AA, Adoukonou-Sagbadja H, Dagba AR, Ahanhanzo C, Agbangla C (2012) Impacts des pratiques culturales sur l'organisation génétique des sorghos cultivés par les Lokpa au Nord-Ouest du Bénin révélés par les marqueurs SSRs. Journal of Applied Biosciences 60 : 4394- 4409

Niangado O, Combes D (1978) Prospection des mils pénicillaires, sorghos et graminées mineures en Afrique de l'Ouest. Bénin. Rapp. IBPGR-ORSTOM.

Ouendeba B, Ejeta G, Hanna WW, Kumar KA (1995) Diversity among African Pearl Millet Landrace Populations. Crop Science 35: 919924.doi:10.2135/cropsci1995.0011183X003500030048x.

Patterson HD, Williams ER (1976)A new class of resolvable incomplete block designs. Biometrica 63: 83-92.doi: 10.2307/2335087.

Pinheiro J, Bates D, DebRoy S, Sarkar D, R Development Core Team (2013) nlme: Linear and Nonlinear Mixed, Effects Models. R package version 3: 1-113.

Rai KN, AppaRao S, Reddy KN (1997) Pearl Millet.Fuccillo D, Sears L, Stapleton P (Eds.)Biodiversity in Trust. Cambridge University Press, Cambridge, UK.

Robert T, Mariac C, Allinne C, Ali K, Beidari Y, Bezançon G, Couturon E, Moussa D, Sasou MS, Seydou M, Seyni O, Tidjani M, Luxereau A (2005) Gestion des semences et dynamiques des introgressions entre variétés cultivées et entre formes domestiques et spontanées des mils (Pennisetum glaucum ssp. glaucum) au Sud-Niger. Les Actes du BRG, 5e colloque national. Un dialogue pour la diversité. Lyon, 3-4-5 novembre 2004.

Russell V, Maxime H (2013) lsmeans: Least-Squares Means. R package version 2.13. http://CRAN.Rproject.org/package=lsmeans

Sadiki M, Jarvis D(2005) Conservation in situ de la diversité génétique des cultures par sa gestion à la ferme dans les agroécosystèmes marocains. Les Actes du BRG 5: 445-464.

Saïdou SIDI, Bakasso Y, Inoussa MM, Zaman-Allah M, Atta S, Barnaud A, Billot C, Saadou M (2014) Diversité agromorphologique des accessions de fonio [Digitaria exilis (Kippist.) Stapf.] au Niger. International Journal of Biology and Chemical Sciences 8: 1710-1729. doi: http://dx.doi.org/10.4314/ijbcs.v8i4.31

Syngenta Foundation for Sustainable Agriculture(2006) Harnessing Modern Science in Africa to Sustain Sorghum and Pearl Millet Production for Resource poor Farmers www.syngentafoundation.com./millet.html

Tostain S (1994) Evaluation de la diversité génétique des mils pénicillaires diploïdes. Pennisetum glaucum (L.) R. Br., au moyen de marqueurs enzymatiques: étude des relations entre formes sauvages et cultivées. Paris, France, ORSTOM, Travaux et documents Micro édités.

Zangré R, Sawadogo M, Ouedraogo M, Balma D (2009) Caractérisation et stratification d'une collection de mil (Pennisetum glaucum (L.) R. Br.) du Burkina Faso. International Journal of Biology and Chemical Sciences 3 : 1042-1056.

Zongo JD (1991) Ressources génétiques des sorghos (Sorghum bicolor L. Moench) du Burkina Faso: Evaluation agromorphologique et génétique. $\mathrm{PhD}$ thesis submitted to University of Abidjan, Côte d'Ivoire. 